\title{
Influence of cellulose polymers type on in vitro controlled release tablets containing theophylline
}

\author{
Evelyn Ojoe, Edna Mitie Miyauchi, Telma Mary Kaneko, \\ Maria Valéria Rolbes Velasco, Vladi Olga Consiglieri*
}

Departamento de Farmácia, Faculdade de Ciências Farmacêuticas, Universidade de São Paulo

*Correspondence:

V.O. Consiglieri

Departamento de Farmácia

Faculdade de Ciências Farmacêutica Universidade de São Paulo

Av Prof Lineu Prestes, 580, Bloco-13 05508-900 - São Paulo - SP - Brazil.

Email: siglieri@usp.br
In this study, the effect of ethylcellulose (EC) and 6 types of hydroxypropylmethylcellulose (Methocel ${ }^{\circledR}$ K100M, K100MPRCR, K15MPRCR, K4MPRCR, K4M PR and E4MCR) on release profile of theophylline from matrix tablets was evaluated. Formulations tablets were prepared by either wet granulation or direct compression technique. The tablets were evaluated for physical characteristics and in vitro release of drug was performed as described in USP 30 ed. (Test 3). All formulations with cellulose polymer produced tablets easily and with physicals characteristics in accordance with official limits. Drug dissolution tests showed that formulations with $15 \%$ of Methocel ${ }^{\circledR}$ K4MPR, $15 \%$ of Methocel $^{\circledR}$ K4MPRCR and $30 \%$ of Ethocel ${ }^{\circledR}$ N10STD, obtained by direct compression method, complied with official specifications, in terms of release profile and diffusion was the main mechanism involved in theophylline delivery.

\section{INTRODUCTION}

Theophylline is a methylxantine derivative very effective in the chronic treatment of bronchial asthma and bronchospastic reactions. Its therapeutic concentration range is narrow (from 10 to $20 \mu \mathrm{g} / \mathrm{mL}$ ) while toxicity usually appears at concentrations above $20 \mu \mathrm{g} / \mathrm{mL}$ and the fluctuations of its serum concentrations can result in variability in clinical response (Parvez et al., 2004; Boswell-Smith, Cazzola, Page, 2006). Theophylline is an example of drug with a narrow therapeutic range that may require drug monitoring both to achieve therapeutic levels and minimize toxicity. In order to overcome these problems, controlled release of theophylline seems to be the most appropriate preparation (Boswell-Smith, Cazzola, Page, 2006; Lordi, 1986; Siepmann, Peppas, 2001).
Several reviews on the use of polymers for controlled release theophylline dosage forms had been reported (Raslan, Maswadeh, 2006; Ikegami, Tagawa, Osawa, 2006). Among the polymers available as possible for matrix-forming materials and multiparticulate systems, such as methacrylic resins, polysaccharidic gel, and hydrophilic polymers, cellulose derivatives appear particularly attractive (Jalal, Zmaily, Najib, 1989; Ford, Rubinstein, Hogan, 1985; Siepmann, Peppas, 2001; Sung et al., 1996; Lopes, Lobo, Costa, 2005).

Cellulose derivatives have been commonly used in the formulation of hydro gel matrices for controlled drug delivery. They are safe, nonionic and minimize interaction problems when used in acidic, basic, or other electrolytic system. They are suitable for preparing formulations with 
soluble or insoluble drugs and at high or low dosage levels. Hydration of polymers results in the formation of a gel layer that controls the release rate of drug (Ojoe et al., 2003; Siepmann, Peppas, 2001; Costa, Souza Lobo, 1999).

The release of drug from controlled release tablets is influenced by factors relating to the physicochemical properties of the drug and to the dosage form. Factors associated with polymers, such as polymer content, molecular weight, concentration, degree of substitution, and particle size, have been shown to have a significant influence on drug release. However, the most important factor that affects the drug release rate from cellulose matrices are the polymer concentration and drug:polymer ratio (Ford, Rubinstein, Hogan, 1985; Mitchell et al., 1993; Xu, Sunada, 1995; Tahara, Yamamoto, Nishihata, 1995).

Despite the high number of papers on this subject, few of them discuss the efficiency of cellulose polymers available commercially. Therefore, the aim of the present work was to evaluate the suitability of different cellulose polymers to prepare theophylline matrix tablets able to assure controlled and well reproducible drug release profiles, also to verify release performances when soluble and insoluble fillers are used, as well as to study drug release profiles by fitting to kinetic models. The cellulose polymers hydroxypropylmethylcellulose (HPMC) and ethylcellulose (EC), the diluents lactose monohydrate and tribasic calcium phosphate, and the lubricant magnesium stearate were studied.

\section{MATERIAL AND METHODS}

\section{Reagents and Materials}

Anhydrous theophylline (Ariston -98060278); hydroxypropylmethylcellulose - Methoce $1^{\circledR} \mathrm{K} 100 \mathrm{M}$, Methoce ${ }^{\circledR}$ K100MPRCR, Methoce ${ }^{\circledR}$ K15MPRCR, Methoce ${ }^{\circledR}$ K4MPRCR, Methoce $1^{\circledR}$ K4M PR and Methoce ${ }^{\circledR}$ E4MCR (Dow Chemical, obtained from Colorcon Brazil), ethylcellulose - Ethoce ${ }^{\circledR}$ N10STD (Dow Chemical), lactose M200 (Henrifarma), tribasic calcium phosphate (Merck), magnesium stearate (Quimibrás Brazil), siliceous dioxide (Henrifarma) and polyvinyl pyrrolidone (PVP) - Kollidon ${ }^{\circledR} 30$ (Basf). Anhydrous theophylline, $99.80 \%$ donated by Ariston, was used as standard in quantitative determinations. Monobasic potassium phosphate (Merck) and hydrochloric acid 37\% (Merck) were of analytic reagent grade. All other reagents were special grade commercial preparations.

\section{Preparation of Theophylline HPMC and EC Matrix Tablets}

Tablet formulations were prepared by directcompression or wet granulation methods.

Batches from HPMC 1 to 5 were prepared by wet granulation and batches from HPMC 6 to 11 and EC were directly compressed. A schematic illustration of the preparation method of the sustained-release theophylline tablets is shown in Figure 1. For the direct compression method, the steps $3,4,5$, and 6 were not included. The composition of the prepared tablets is listed in Tables I, II and III. Then, tablets (diameter, $10 \mathrm{~mm}$ ) containing $200 \mathrm{mg}$ of theophylline were obtained by the Fabbe single punch machine. The compression forces were adjusted for the different formulations to obtain similar tablet hardness.

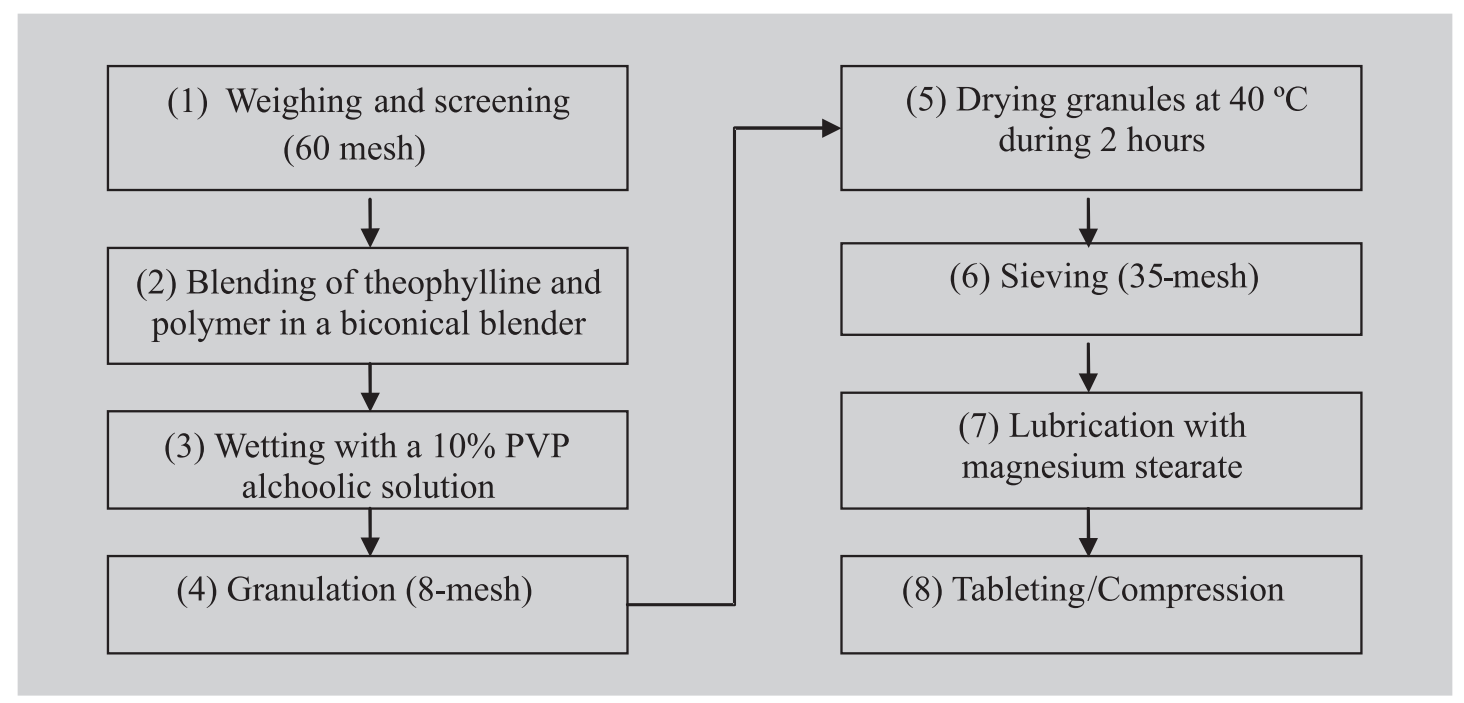

FIGURE 1 - Schematic illustration of theophylline tablets preparation. 
TABLE I - Composition of hydroxypropylmethylcellulose (Methocel ${ }^{\circledR} \mathrm{K} 100 \mathrm{M}$ ) matrix formulations prepared by wet granulation

\begin{tabular}{lccccc}
\hline Contents (\%) & HPMC 1 & HPMC 2 & HPMC 3 & HPMC 4 & HPMC 5 \\
\hline Theophylline & 66.67 & 66.67 & 66.67 & 66.67 & 66.67 \\
${\text { Methocel }{ }^{\circledR} \text { K100M }}_{\text {Magnesium stearate }}^{10.00}$ & 20.00 & 10.00 & 20.00 & 10.00 \\
Kollidon $^{\circledR}$ 30 & 3.00 & 3.00 & 3.00 & 3.00 & 0.50 \\
Calcium phosphate $_{\text {Lactose }}^{10.00}$ & 10.00 & 10.00 & 10.00 & 10.00 \\
& 0.00 & 0.00 & 10.33 & 0.33 & 0.00 \\
\hline
\end{tabular}

TABLE II - Composition of hydroxypropylmethylcellulose (Methoce ${ }^{\circledR}$ K4MPR; K4MPRCR; K100MPRCR; K15MPRCR) matrix formulations prepared by direct compression

\begin{tabular}{lcccc}
\hline Contents $(\%)$ & HPMC 6 & HPMC 7 & HPMC 8 & HPMC 9 \\
\hline Theophylline & 66.67 & 66.67 & 66.67 & 66.67 \\
Methoce $l^{\circledR}$ K4MPR & 15.00 & 0.00 & 0.00 & 0.00 \\
Methoce ${ }^{\circledR}$ K4MPRCR & 0.00 & 15.00 & 0.00 & 0.00 \\
Methoce ${ }^{\circledR}$ K100MPRCR & 0.00 & 0.00 & 15.00 & 0.00 \\
Methoce ${ }^{\circledR}$ K15MPRCR & 0.00 & 0.00 & 0.00 & 15.00 \\
Magnesium stearate & 0.50 & 0.50 & 0.50 & 0.50 \\
Lactose & 17.83 & 17.83 & 17.83 & 17.83 \\
\hline
\end{tabular}

TABLE III - Composition of hydroxypropylmethylcellulose (Methoce ${ }^{\circledR}$ E4MCR; K100M) and ethylcellulose (Ethocel ${ }^{\circledR}$ N10STD) matrix formulations prepared by direct compression

\begin{tabular}{lcrr}
\hline Contents $(\%)$ & HPMC 10 & HPMC 11 & EC \\
\hline Theophylline & 66.67 & 66.67 & 66.67 \\
Methocel ${ }^{\circledR}$ E4MCR & 31.33 & 0.00 & 0.00 \\
Methoce ${ }^{\circledR}$ K100M & 0.00 & 31.33 & 0.00 \\
Ethocel ${ }^{\circledR}$ N10STD & 0.00 & 0.00 & 31.33 \\
Magnesium stearate & 0.50 & 0.50 & 0.50 \\
Lactose & 1.50 & 1.50 & 1.50 \\
\hline
\end{tabular}

\section{Determination of theophylline from HPMC matrix tablets}

Theophylline content in tablets was determined by spectrophotometric analysis at $270 \mathrm{~nm}$ using a Shimadzu UV 1601 analyzer. The tablets were powdered and aliquots theoretically corresponding to $200 \mathrm{mg}$ of theophylline were transferred to $200 \mathrm{~mL}$ volumetric flasks and mixtured with $200 \mathrm{~mL}$ of distilled water, in an ultrasound apparatus, for 5 minutes. After centrifugation, samples of $1 \mathrm{~mL}$ were taken, diluted to $100 \mathrm{~mL}$ with simulated gastric fluid $(\mathrm{pH}$
1.2). Simultaneously, a $10 \mu \mathrm{g} / \mathrm{mL}$ theophylline standard solution was recorded. The assay of theophylline in formulations was carried out in triplicate.

\section{Physical tests}

The compressed tablets were characterized by their physical properties. The average tablet weight was determined from 20 tablets (USP, 2007).

Hardness of the tablets was tested using a Pharma Test PTB 311 hardness tester. Friability of the tablets was 
determined in an Etica friabilator. Tablet friability was calculated as the percentages of weight loss of 20 tablets after 100 rotations (USP, 2007).

\section{In vitro dissolution tests}

Dissolution measurements were carried out in a USP 30 ed. method described for theophylline extended-release capsules (test 3 ) at $37 \pm 0.5^{\circ} \mathrm{C}$, with paddle at $50 \mathrm{rpm}$ and $900 \mathrm{~mL}$ of dissolution medium using $\mathrm{pH} 1.2$ simulated gastric fluid for the first $1 \mathrm{~h}$ and $\mathrm{pH} 7.5$ of simulated intestinal fluid for the following $6 \mathrm{~h}$. Samples of $10 \mathrm{~mL}$ were taken from the dissolution medium at appropriate intervals and the absorbancies were measured by UV spectrophotometer at 270 and $271 \mathrm{~nm}$. These values of the drug released from tablets were plotted in graphs of drug released versus time. For elucidation of the drug release mechanism, dissolution data were analyzed using zero order, first order and Higuchi equations, with linear regression (Chambin et al., 2004; Manadas, Pina, Veiga, 2002).

\section{RESULTS AND DISCUSSION}

Theophylline tablets provided good weight uniformity, according to $7.5 \%$ of variation, referring to tablets with weight between $200 \mathrm{mg}$ and $300 \mathrm{mg}$ (United States Pharmacopoeia, 2007). All the formulations were within the USP limits for friability $(<1 \%$ weight loss), hardness, diameter and height (Table IV). The tablets showed no physical defects such as capping or lamination (USP, 2007).

Cellulose polymers showed to be efficient to control the theophylline release from the tablets. As polymer percentages increased in tablet formulations, the amounts of drug delivered decreased in dissolution tests (Figure 2). The effect of fillers on drug release was observed in formulations using $10 \%$ and $20 \%$ of Methocel ${ }^{\circledR} \mathrm{K} 100 \mathrm{M}$ with lactose (HPMC 1 and HPMC 2) or tribasic calcium phosphate (HPMC 3 and HPMC 4). Higher quantities of drug dissolved were obtained from formulations with soluble fillers (Figure 2).

Tablets with $10 \%$ of Methoce ${ }^{\circledR} \mathrm{K} 100 \mathrm{M}$ released about $92 \%$ of the drug after 420 min when $0.5 \%$ of magnesium stearate and lactose were used (HPMC 5); therefore the addition of $3.0 \%$ of magnesium stearate to the similar formulation (HPMC 1) resulted in 74\% of dissolved drug (Figure 2). According to Hussain, York, Timmins (1992) dissolution rate retardation in the presence of magnesium stearate has been attributed to the formation of a hydrophobic film on the surface of the particles. This hydrophobic barrier might effectively result in reduced wettability and reduced particle surface area available for dissolution.

Dürig, Venkatesh, and Fassihi (1999) related that magnesium stearate is a critical erosion-controlling excipient, particularly if it is used over $1.0 \%$. In an investigation of controlled release tablets using HPMC, they observed that high levels of magnesium stearate $(>2.5 \%)$, influenced the balance between radial and axial

TABLE IV - Tablets data from physicochemical analyses and drug content. Relative standard deviations (\%) are in parenthesis

\begin{tabular}{lcccccc}
\hline Formulation & $\begin{array}{c}\text { Weight } \\
(\mathrm{mg})\end{array}$ & $\begin{array}{c}\text { Drug content } \\
\% \mathrm{w} / \mathrm{w}\end{array}$ & $\begin{array}{c}\text { Friability } \\
\%\end{array}$ & $\begin{array}{c}\text { Hardness } \\
(\mathrm{kgf})\end{array}$ & $\begin{array}{c}\text { Diameter } \\
(\mathrm{mm})\end{array}$ & $\begin{array}{c}\text { Height } \\
(\mathrm{mm})\end{array}$ \\
\hline HPMC 1 & $303.16(5.87)$ & 103.44 & 0.61 & $4.59(0.06)$ & $10.07(0.03)$ & $4.34(0.27)$ \\
HPMC 2 & $300.60(5.99)$ & 99.07 & 0.82 & $4.64(0.11)$ & $10.06(0.01)$ & $4.09(0.09)$ \\
HPMC 3 & $298.90(1.50)$ & 103.39 & 0.22 & $4.59(0.11)$ & $9.92(0.41)$ & $4.12(1.33)$ \\
HPMC 4 & $302.73(4.02)$ & 101.01 & 0.31 & $6.78(0.07)$ & $10.04(0.02)$ & $4.12(0.02)$ \\
HPMC 5 & $310.40(6.19)$ & 93.38 & 0.42 & $5.20(0.81)$ & $10.03(0.02)$ & $3.96(0.11)$ \\
HPMC 6 & $303.79(8.88)$ & 97.60 & 0.75 & $9.44(0.20)$ & $10.03(0.03)$ & $3.86(0.15)$ \\
HPMC 7 & $296.48(9.45)$ & 96.78 & 0.81 & $9.03(0.33)$ & $10.03(0.05)$ & $3.68(0.17)$ \\
HPMC 8 & $300.42(8.75)$ & 98.42 & 0.56 & $7.29(0.12)$ & $10.02(0.03)$ & $3.96(0.33)$ \\
HPMC 9 & $303.58(9.54)$ & 96.41 & 0.86 & $9.95(0.39)$ & $10.03(0.05)$ & $3.60(0.16)$ \\
HPMC 10 & $292.35(13.41)$ & 95.01 & 0.64 & $7.35(0.29)$ & $10.05(0.02)$ & $4.33(0.29)$ \\
HPMC 11 & $296.55(8.90)$ & 90.66 & 0.44 & $8.72(0.43)$ & $10.02(0.01)$ & $4.38(0.28)$ \\
EC & $295.56(10.46)$ & 94.74 & 0.72 & $5.56(0.29)$ & $10.07(0.03)$ & $4.49(0.32)$ \\
\hline
\end{tabular}

HPMC - Formulations with hydroxypropylmethylcellulose; EC - formulation with ethylcellulose 


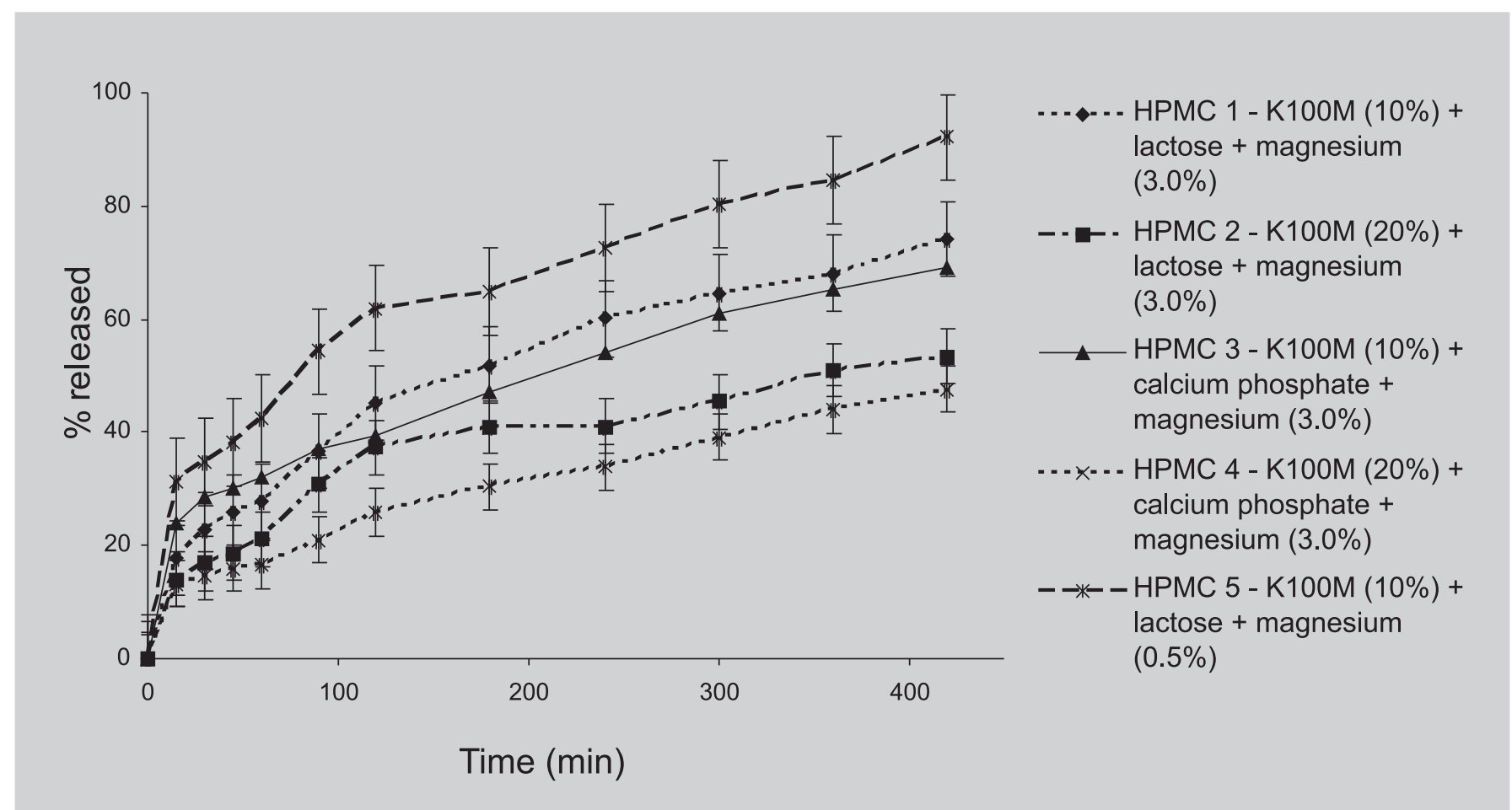

FIGURE 2 - Effect of polymer type, excipient type and lubricant concentration on release of theophylline from tablet formulations.

erosion rates, leading to lower percentages of drug dissolved. This fact is of particular importance when drugs with poor solubility, like theophylline, are formulated with high amounts of this lubricant, because, as stated by Sung et al. (1996), they are released preferentially by erosion while soluble drugs can dissolve and diffuse through the hydrated gel layer (Reza, Quadir, Haider, 2003; Ibrhim, Daes, Bangudu, 2000).

The dissolution assay results demonstrated that the amount of polymer used was very important to control the drug release. According to Figure 3, the theophylline release profiles from formulations with $15 \%$ of Methocel $^{\mathbb{R}}$ K4MPR (HPMC 6) and Methocel ${ }^{\circledR}$ K4MPRCR (HPMC 7) was similar. Both of them showed a slight difference in their dissolution profiles and higher percentage of drug dissolved than the other formulations containing $15 \%$ of Methoce ${ }^{\circledR}$ K100MPRCR (HPMC 8) and K15MPRCR (HPMC 9) polymers. The letters CR of the Methocel ${ }^{\circledR}$ refers to controlled-release grade, represented by ultra-fine particle size materials, that is able to hydrate fast, leading to effective formation of protective gel barrier. In this research, however, no difference regarding theophylline release was found when CR polymers were used (Figure 3 ). In addition, Figure 3 shows the influence of polymer viscosity on the theophylline release by comparing HPMC 6 and HPMC 7 with HPMC 8 and HPMC 9.
However, in our work, no significant differences were observed between the release profiles from HPMC 8 and HPMC 9 formulations, with $15 \%$ of Methocel $^{\circledR}$ K100MPRCR and $15 \%$ of Methocel ${ }^{\circledR}$ K15MPRCR, respectively. Similar reports were found in literature by Sung et al. (1996) that reported no differences on the adinazolam mesilate release between formulations produced with Methocel ${ }^{\circledR} \mathrm{K} 15 \mathrm{M}$ and Methocel ${ }^{\circledR} \mathrm{K} 100 \mathrm{M}$. They concluded that there were limitations in the polymer viscosity when small amounts are used.

Methoce ${ }^{\circledR} \mathrm{K}$ and $\mathrm{E}$ possess different ratios of hydroxypropyl and methyl substitution, which influences properties such as organic solubility and thermal gelation temperature of aqueous solutions. The texture and the strength of gel produced by these polymers vary with the type, viscosity grade, and concentration of polymer used. The size, shape and ionization of the drug affect its diffusion through the gel layer. The drug diffusion through most types of polymeric systems is often best described by Fickian diffusion (Patel, Patel, 2007).

The viscosity of the polymers had a dominant role as controlling factors on kinetics of drug release. In general, the strength of the gel increases with increasing molecular weight (Patel, Patel, 2007). K100M is the higher molecular weight polymer, consequently, in the systems with different viscosity grades of K-Methoce ${ }^{\circledR}$ products, the release rates 
decreased with increasing polymer molecular weights, according to the Figure 4.

The substitution's groups are essential for the polymer hydration of controlled release systems and the choice of polymer is very important because the fast polymer hydration is needed to form the gel barrier, and this gel layer should be sufficiently strong to control the drug and water diffusion. For this reason, the K-polymers

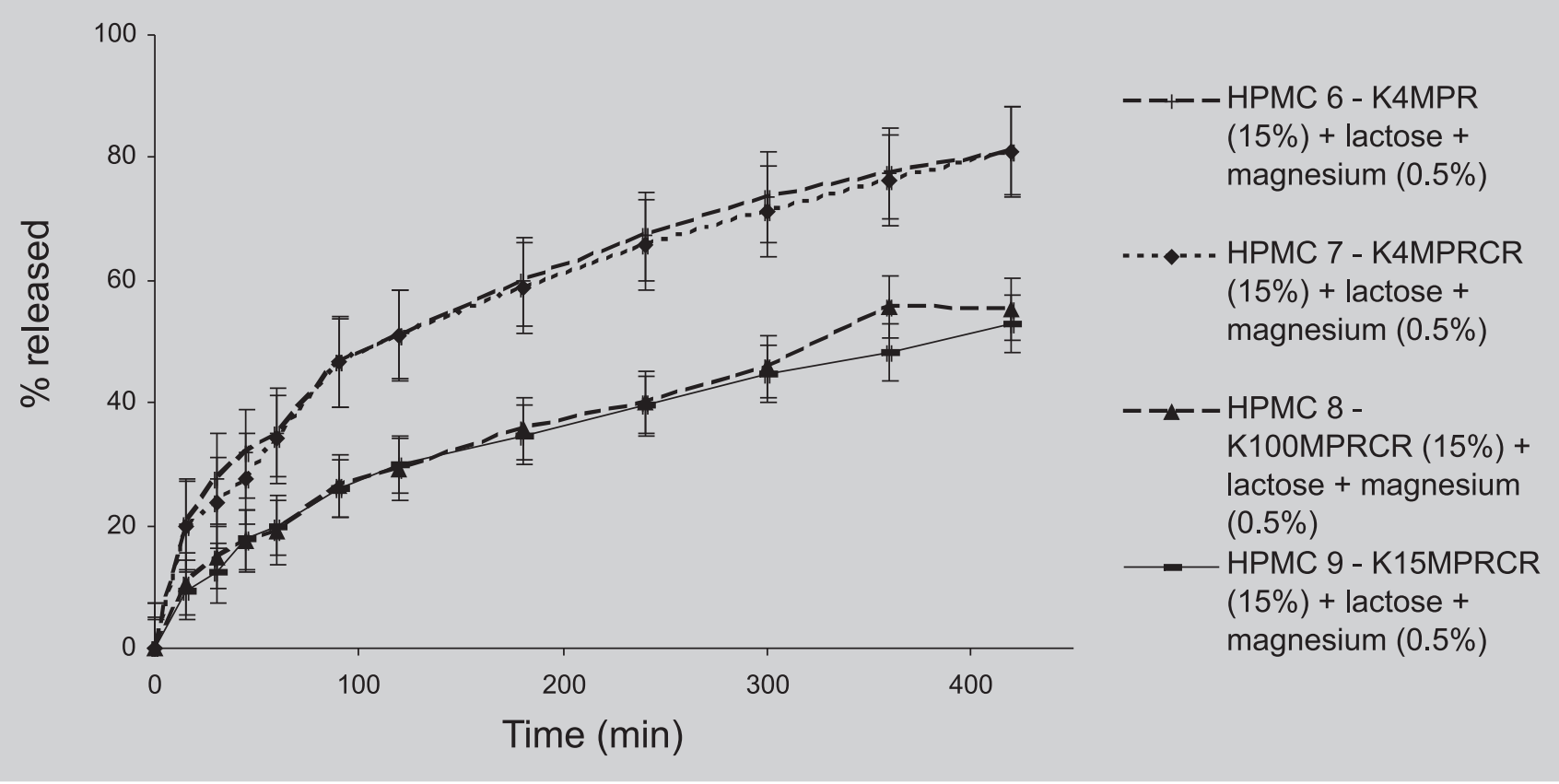

FIGURE 3 - Effect of polymer type, excipient type and lubricant concentration on release of theophylline from tablet formulations.

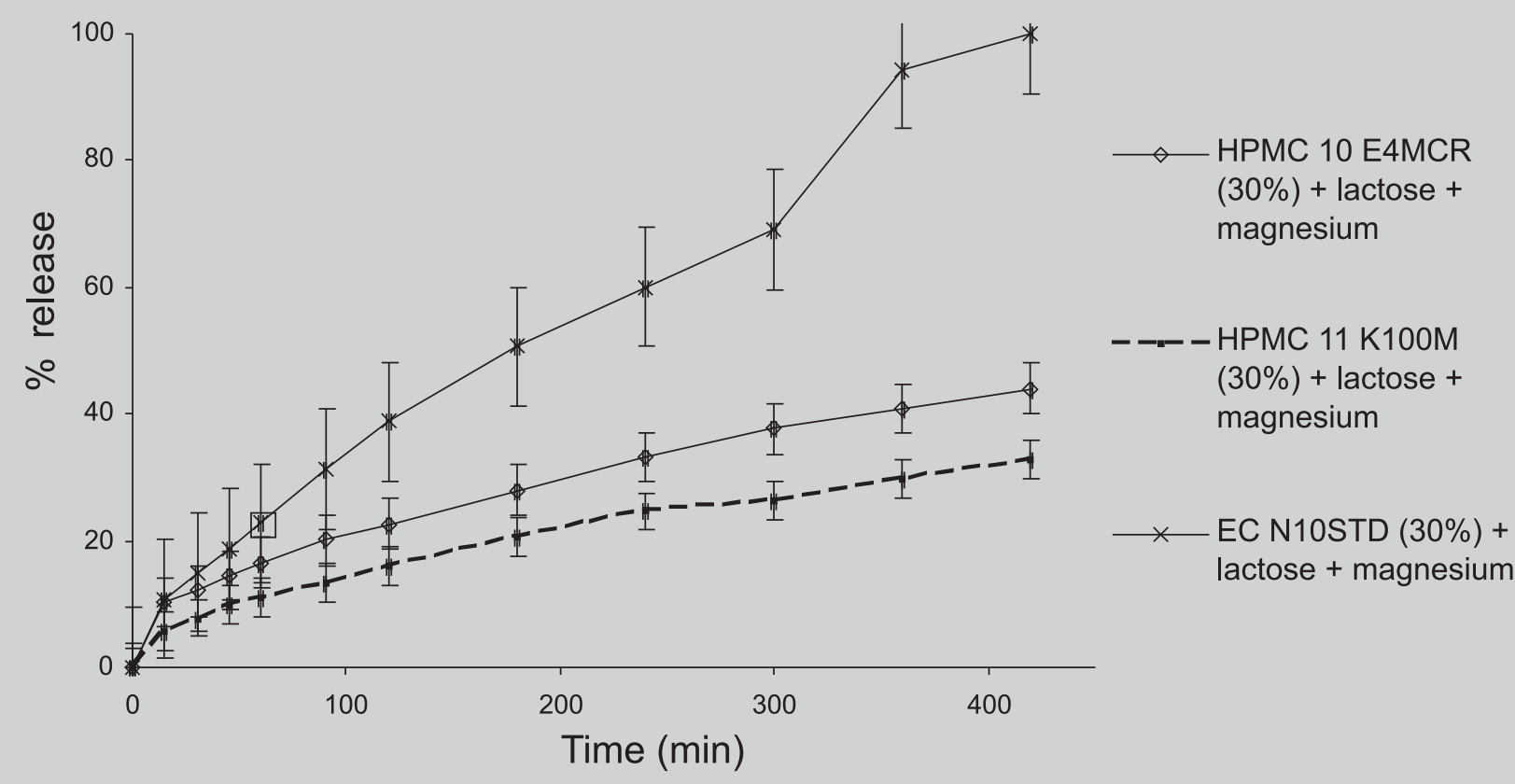

FIGURE 4 - Effect of polymer type, lactose excipient and lubricant concentration on release of theophylline from tablet formulations. 
TABLE V - Kinetic assessment: correlation coefficient (r) of kinetics model, dissolution rate $(\mathrm{kd})$ half-life of release $\left(\mathrm{Td}_{50 \%}\right)$

\begin{tabular}{lccccc}
\hline Formulations & \multicolumn{4}{c}{ Coefficients of correlation $(\mathrm{r})$} \\
& Zero-order & First-order & Higuchi & $\mathrm{Kd}\left(\mathrm{min}^{-1}\right)$ & $\operatorname{Td}_{50 \%}(\min )$ \\
\hline HPMC 1 & 0.8404 & 0.9664 & 0.9709 & 0.0408 & 93.49 \\
HPMC 2 & 0.8519 & 0.9216 & 0.9655 & 0.0330 & 194.31 \\
HPMC 3 & 0.8705 & 0.9603 & 0.9753 & 0.0305 & 193.62 \\
HPMC 4 & 0.9317 & 0.9679 & 0.9890 & 0.0220 & 490.02 \\
HPMC 5 & 0.8705 & 0.9767 & 0.9930 & 0.0358 & 176.49 \\
HPMC 6 & 0.8687 & 0.9890 & 0.9877 & 0.0032 & 79.91 \\
HPMC 7 & 0.8763 & 0.9890 & 0.9868 & 0.0035 & 80.34 \\
HPMC 8 & 0.9324 & 0.9839 & 0.9946 & 0.0285 & 314.96 \\
HPMC 9 & 0.9330 & 0.9878 & 0.9983 & 0.0247 & 417.51 \\
HPMC 10 & 0.9365 & 0.9695 & 0.9973 & 0.0211 & 551.91 \\
HPMC 11 & 0.9528 & 0.9726 & 0.9959 & 0.0161 & 995.56 \\
EC & 0.9852 & 0.6021 & 0.9562 & 0.0023 & 184.10 \\
\hline
\end{tabular}

hydrated result on stronger barrier than those formed by Epolymers. Methoce ${ }^{\circledR} \mathrm{K}$ has the highest ratio of hydroxypropoxyl to methoxyl substitution.

Comparing HPMC 10, HPMC 11 and EC formulations, when $30 \%$ of polymer was used (Methocel ${ }^{\circledR}$ E4MCR, K100M and Ethocel ${ }^{\circledR}$ N10STD), higher quantities of drug dissolved were obtained from tablets formulated with Ethoce ${ }^{\circledR}$ N10STD (Figure 4).

Formulations HPMC 6, HPMC7 and EC corresponding respectively to Methoce ${ }^{\circledR}$ K4MPR (15\%), Methoce $l^{\circledR}$ K4MPRCR (15\%) and Ethoce ${ }^{\circledR}$ N10STD $(30 \%)$ showed amount of theophylline release (\%) according to specifications in Test 3, USP 30. The release data of matrix tablets were fitted into various mathematical models (zero, first, Higuchi's square root equation) to evaluate the kinetics and mechanism of drug release from the tablets. The model that best fits the release data is selected based on the correlation coefficient $(r)$ value in various models. The model that gives high ' $r$ ' value is considered as the best fit of the release data. The ' $r$ ' values in zero, first order and Higuchi models are given in Table V. It was found Higuchi as a kinetic model that best fitted in the majority of the formulations tested and for the others, first-order (Chowdary, Mohapatra, Murali Krishna, 2006).

Drug release from matrix tablets, in general, becomes progressively slower with time, like Higuchi's model, in which the amount of drug released is proportional to the square root of time. Kinetic models which fit zero order and Higuchi are more suitable for controlled release formulations, while first order model is more appropriate for conventional tablets (Chowdary, Mohapatra, Murali Krishna, 2006).
The analysis of the $\mathrm{Td}_{50 \%}$ and $\mathrm{Kd}$ values (Table V) revealed that the release kinetics is mainly affected by cellulose polymer and excipient type (lactose and calcium phosphate) content.

\section{CONCLUSION}

The mixing formulation of granules formed with theophylline and cellulose polymers like Methoce ${ }^{\circledR}$ and Ethocel ${ }^{\circledR}$ to prepare oral controlled release tablets showed appropriate compression.

Theophylline tablets prepared with Methoce ${ }^{\circledR}$ K100M polymer, showed influence on percentage of drug release when amounts of $10 \%$ and $20 \%$ of polymer was used, also the type of diluents (soluble and insoluble) and amount of lubricant showed significant differences. Higher quantities of drug dissolved were obtained from formulations using $10 \%$ of Methocel ${ }^{\circledR} \mathrm{K} 100 \mathrm{M}$ with lactose and $0.5 \%$ of magnesium stearate.

The studies showed that the theophylline release profiles from formulations with $15 \%$ of Methocel $^{\circledR}$ K4MPR and Methoce ${ }^{\circledR}$ K4MPRCR was similar and no difference regarding theophylline release was found when CR polymers were used. Formulations with $15 \%$ of Methoce $1{ }^{\circledR}$ K4MPR or $15 \%$ of Methoce ${ }^{\circledR}$ K 4MPRCR showed higher amount percentage of drug dissolved if comparing with formulations containing $15 \%$ of K100MPRCR or $15 \%$ of K15MPRCR polymers.

The hydrated K-polymers result on stronger barrier than those formed by E-polymers, for this reason Methoce ${ }^{\circledR} \mathrm{K}$ showed lower amount percentage of drug dissolved if comparing with Methocel E. 
The fit to the Higuchi model indicated that the drug release mechanism from these polymers matrices was controlled by the diffusion.

Dissolution rate was higher for EC than for HPMC excipients, but both formulations showed adequate chemical analyses data and these results demonstrated that Methoce ${ }^{\circledR}$ and Ethoce $l^{\circledR}$ were a useful material for a controlled release tablet.

\section{RESUMO}

\section{Desenvolvimento e avaliação de comprimidos matriciais de teofilina baseados em ésteres da celulose}

Os efeitos das variáveis das formulações na liberação da teofilina a partir da hidroxipropilmetilcelulose (HPMC) e etilcelulose (EC) em comprimidos matriciais foram estudados. Formulações de comprimidos foram preparadas pelos métodos da granulação úmida ou compressão direta usando diferentes viscosidades de HPMC. Propriedades físico-químicas dos comprimidos e liberação do fármaco foram estudadas conforme dissolução descrita no Teste 3 da Farmacopéia Americana 30ed. Ensaios "in vitro" mostraram que as formulações com $15 \%$ de Methocel $^{\mathbb{}}$ K4MPR, $15 \%$ de Methocel ${ }^{\circledR}$ K4MPRCR e $30 \%$ de Ethocel ${ }^{\circledR}$ N1OSTD obtidas por compressão direta apresentaram bom perfil de liberação de teofilina e a difusão foi o principal mecanismo envolvido na liberação.

UNITERMOS: Teofilina. Liberação modificada. Matrizes. Hidroxipropilmetilcelulose. Etilcelulose.

\section{ACKNOWLEDGMENTS}

The authors thank Ariston Ind. Quim. Farm. Ltda for gently supplying anhydrous theophylline; Colorcon of Brazil Ltda for donating Dow Chemical products and Capes/USP financial support, also Mr Marcelo Guimarães for his very kind help in reviewing the text.

\section{REFERENCES}

BOSWELL-SMITH, V.; CAZZOLA, M.; PAGE, C. P. Are phosphodiesterase 4 inhibitors just more theophylline? $J$. Allergy Clin. Immunol., v.117, p.1237-1243, 2006.

CHAMBIN, O.; CHAMPION, D., DEBRA,Y. C.; ROCHAT-GONTHIER, M. H.; LE MESTE, M.; POURCELOT, Y. Effects of different cellulose derivatives on drug release mechanism studied at a preformulation stage. J. Control. Release, v. 95, p. 101-108, 2004.
CHOWDARY, K. P. R.; MOHAPATRA, P.; MURALI KRISHNA, M. N. Evaluation of olibanum and its resin as rate controlling matrix for controlled release of diclofenac. Indian. J. Pharm. Sci., v.68, p.497-500, 2006.

COSTA, P.; SOUZA-LOBO, J. M. Formas farmacêuticas de liberação modificada. Rev. Port. Farm., v. 59, p. 181-190, 1999.

DÜRIG, T.; VENKATESH, G. M.; FASSIHI, R. An investigation into the erosion behavior of a high drug-load $(85 \%)$ particulate system designed for an extended-release matrix tablet. Analysis of erosion kinetics in conjunction with variations in lubrication; porosity; and compaction rate. J. Pharm. Pharmacol., v. 51, p. 1085-1092, 1999.

FORD, J. L.; RUBINSTEIN, M. H.; HOGAN, J. E. Formulation of sustained release promethazine hydrochloride tablets using hydroxypropylmethylcellulose matrices. Int. J. Pharm., v. 24, p. 327-338, 1985.

HUSSAIN, M . S. H.; YORK, P.; TIMMINS, P. Effect of commercial and high purity magnesium stearates on invitro dissolution of paracetamol DC tablets. Int. J. Pharm., v. 78, p. 203-207, 1992.

IBRHIM, M. A; DAES, V. H.; BANGUDU, A. B. The contributions of erosion, swelling, and porosity to theophylline release kinetics from Cissus populnea polymer matrices. Drug Dev. Ind. Pharm., v. 26, p. 571575,2000 .

IKEGAMI, K; TAGAWA, K.; OSAWA, T. Bioavailability and in vivo release behavior of controlled-release multipleunit theophylline dosage forms in beagle dogs, cynomolgus monkeys, and göttingen minipigs. J. Pharm. Sci., v.95, p.1888-1895, 2006.

JALAL, I.; ZMAILY, E.; NAJIB, N. Dissolution kinetics of commercially avilable controlled-release theophylline preparations. Int. J. Pharm., v.52, p.63-70, 1989.

LOPES, C. M.; LOBO, J. M. S.; COSTA, P. Formas farmacêuticas de liberação modificada: polímeros hidrofilicos. Rev. Bras. Ciên. Farm., v.41,n.2, p. 143-154, abr.jun., 2005.

LORDI, N. Sustained release dosage forms. In: LACHMAN, L., LIEBERMAN, H. A., KANIG, J. L., (Eds.). The theory and practice of industrial pharmacy. Philadelphia: Lea and Febiger, 1986. p.430-478. 
MANADAS, R.; PINA, M. E.; VEIGA, F. A dissolução in vitro na previsão da absorção oral de fármacos em formas farmacêuticas de liberação modificada. Rev. Bras. Ciên. Farm., v.38, n.4, p. 375-399, 2002.

MITCHELL, K.; FORD, J. L.; ARMSTRONG, D. J.; ELLIOT, P. N. C.; HOGAN, J. E.; ROSTRON, C. The influence of substitution type on the performance of methyl cellulose and hydroxypropylmethylcellulose in gels and matrices. Int. J. Pharm., v. 100, p.143-154, 1993.

OJOE, E.; MIYAUCHI, E. M.; SAKUDA, T. M.; VELASCO, M. V.; CONSIGLIERI, V. O. Studies on controlled-release of theophylline from matrix tablet formulation. Rev. Bras. Ciênc. Farm., v.39, supl.3, 2003.

PARVEZ, N.; AHMED, T.; MONIF, T.; SAHA, N.; SHARMA, P. L. Comparative bioavailability of three oral formulations of sustained release theophylline in healthy human subjects. Indian J. Pharmacol., v.36, p.29-33, 2004.

PATEL, V. F.; PATEL, N. M. Statistical evaluation of influence of viscosity of polymer and types of filler on dipyridamole release from floating matrix tablets. Int. $J$. Pharm. Sci., v. 69, p. 51-57, 2007.

RASLAN, H. K.; MASWADEH, H. In vitro dissolution kinetic study of theophylline from mixed controlled release matrix tablets containing hydroxypropylmethyl cellulose and glycerylbehenate. Indian J. Pharm. Sci., v.68, p.308312, 2006.
REZA, M. S.; QUADIR, M.A.; HAIDER, S. S. Comparative evaluation of plastic, hydrophobic and hydrophyllic polymers as matrices for controlled-release drug delivery. J. Pharm. Pharmaceut. Sci., v.6, p.274-291, 2003.

SIEPMANN, J.; PEPPAS, N. A. Modeling of drug release from delivery systems based on hydroxypropylmethylcellulose (HPMC). Adv. Drug Rev., v.48, p.139157, 2001.

SUNG, K. C.; NIXON, P. R.; SKOUG, J. W.; JU, T. R.; GAO, P. Effect of formulation variables on drug and polymer release from HPMC-based matrix tablets. Int. J. Pharm., v.142, p.53-60, 1996.

TAHARA, K.; YAMAMOTO, K.; NISHIHATA, T. Overall mechanism behind matrix sustained release (SR) tablets prepared with hydroxypropyl methylcellulose 2910. J. Control. Release, v.35, p. 59-66, 1995.

UNITED States Pharmacopeia. 30 ed. Rockville: United States Pharmacopeia Convention, 2007. p. 1941-1950.

XU, G.; SUNADA, H. Influence of formulation change on drug release kinetics from hydroxypropylmethylcellulose matrix tablets. Chem. Pharm. Bull., v.43, p.483-487, 1995.

Recebido para publicação em 14 de agosto de 2006. Aceito para publicação em 17 de maio de 2007. 